Jan Paweł II. Posługa myślenia, t. 2, red. ks. B. Kastelik, A. Krupka, ks. R. Woźniak, Kraków 2015, s. 363-380

(Studia nad Myślą Jana Pawła II, 17).

DOI: http://dx.doi.org/10.15633/9788374384933.17

Teresa Grabińska

\title{
BEZPIECZEŃSTWO SPOLECZNE W ENCYKLIKACH JANA PAWŁA II I W NAUCZANIU FRANCISZKA
}

Termin „bezpieczeństwo” pojawia się ostatnio w licznych publikacjach prasowych, publikacjach o charakterze naukowym, projektach badawczych. Otwierane są kierunki studiów kształcące specjalistów w zapewnianiu bezpieczeństwa, rozwija się dynamicznie wytwórstwo środków i sprzętu pomagających w utrzymaniu bezpieczeństwa. Nasuwa się pytanie, czy rzeczywiście współcześnie w drastyczny sposób wzrósł poziom zagrożeń, aby w tak systematyczny i zmasowany sposób zajmować się bezpieczeństwem?

Gdy poszukać przyczyn nadzwyczajnego skupiania się na coraz to nowych zagrożeniach zdrowia i życia osób, społeczności i państw, okaże się, że oto wśród firm produkujących środki i sprzęt do zapewnienia bezpieczeństwa prym wiodą firmy zajmujące się wytwarzaniem uzbrojenia i zaopatrzenia wojska ${ }^{1}$, a więc firmy produkujące środki bojowe równocześnie zajmują się szeroko pojętym bezpieczeństwem. Z jednej strony to nic nowego, bo miecz może służyć zarówno do ataku, jak i do obrony. Zastanawiająca jest raczej kwestia, na ile konieczność obrony przed zagrożeniami jest realna, a na ile jest tworzona $\mathrm{w}$ ramach komercji, $\mathrm{w}$ ramach powszechnie stosowanej manipulacji, kreowania potrzeb konsumentów na rynku. W tym jednak przypadku owo kreowanie potrzeb samo w sobie może być groźne. Odbywa się ono bowiem w systematycznych medialnych kampaniach wywołujących

$1 \quad$ Np. brytyjski wielonarodowy koncern BAE Systems, amerykański globalny koncern Northrop Grumman, amerykański wielonarodowy producent United Technologies Corporation, izraelski producent Hatehof Ltd. 
u człowieka poczucie stałej niepewności, lęku, strachu, braku zaufania do siebie i innych, utraty identyfikacji z rodziną - najbliższą kulturowo grupą społeczną; koncentrowania się na samozachowaniu². Jeszcze groźniejsze mogą być skutki społeczne mobilizowania całych populacji do walki z zagrożeniami, pochodzącymi od innej populacji - zagrożeniami, które na początku nie zawsze są realne, a czasem są też kreowane, tzn. prowokowane jako mniej lub bardziej lokalne konflikty zbrojne.

Nowe zagrożenia, paradoksalnie powodowane zabiegami w celu zapewnienia bezpieczeństwa personalnego i społecznego, mogą być rozpatrywane jako współczesny przejaw walki ekonomicznej i politycznej. Skoro jako przejaw, to ich przyczyny są głębsze i bardziej fundamentalne niż takie lub inne trendy technologiczne i ekonomiczne. Dlatego warto kolejny raz przypomnieć podstawowe diagnozowanie stanu społeczności ludzkiej, prowadzone przez ostatnich papieży. Ze względu na ograniczoną objętość tej publikacji skupimy się na analizie nauczania społecznego Jana Pawła II ${ }^{3}$ i Franciszka ${ }^{4}$. Wynik tej analizy pokaże, po pierwsze, jak Franciszek kontynuuje myśl społeczną Jana Pawła II, po drugie, że papieskie diagnozy przyczyniają się do wyjaśnienia współczesnego zjawiska lęku przed zagrożeniami, po trzecie wreszcie, że pojemny znaczeniowo termin „bezpieczeństwo” przekłada się na inne terminy personalistycznej koncepcji człowieka i społeczności.

2 Jak samozachowanie w antropologii Tomasza Hobbesa: T. Hobbes, Lewiatan, czyli materia, forma i władza państwa kościelnego i świeckiego, tłum. C. Znamierowski, Warszawa 2005, cz. 1. Por. też: T. Grabińska, Usposobienie do melancholii w antropologii fundującej pesymizm moralny, [w:] Przeciw melancholii. W 40. rocznicę wydania "Melancholii” Antoniego Kępińskiego. Perspektywa Fides i Ratio, red. A. Hennel-Brzozowska, S. Jaromi OFM Conv, Kraków 2014, s. 157-175.

W nauczaniu społecznym Jana Pawła II zajmiemy się przede wszystkim jego trzema encyklikami społecznymi: Jan Paweł II, enc. Laborem exercens [dalej: LE]; tenże, enc. Sollicitudo rei socialis [dalej: SRS]; tenże, enc. Centesimus annus [dalej: CA].

4 W nauczaniu Franciszka zajmiemy się adhortacją apostolską Evangelii gaudium [dalej: EG], Rzym 2014; wydanie polskie: Wrocław 2014. Część rozważań niniejszego artykułu została przedstawiona na lutowym seminarium, organizowanym przez Międzynarodowe Towarzystwo Naukowe „Fides et Ratio”, Uniwersytet im. Jana Pawła II, Kraków 2014. Referat miał tytuł Tropy pojęciowe ewangelizacji Ojca Świętego Franciszka w adhortacji apostolskiej „Evangelii gaudium”. Oprócz wkładu autorki swoje części przedstawili Ewa Leś i ks. Szymon Drzyżdżyk. 


\section{Perspektywa osoby w naukach o bezpieczeństwie}

Bezpieczeństwo społeczne jest bezpośrednio związane z bezpieczeństwem personalnym ${ }^{5}$, bezpieczeństwem osoby, bezpieczeństwem obywatela - jeśli osobę traktować jak członka społeczności zorganizowanej prawem stanowionym. W tej relacji związku bezpieczeństwa personalnego i społecznego należy mieć wciąż na uwadze jej zwrot. Zwrot relacji od pozytywistycznie pojmowanej wiedzy o społeczeństwie ku wiedzy o człowieku jest charakterystyczny dla nurtu socjologistycznego (z elementami psychologii czy etnologii). Osiągnięcia w ramach tego nurtu powodują, że jego działy wiedzy szczegółowej w istotny sposób wzbogacają wiedzę o ludzkiej naturze. Nie powinny jednak w postaci tzw. nauki o obyczajach, jak to się współcześnie dzieje, zastępować etyki jako filozofii moralnej ${ }^{6}$ - wiedzy racjonalnej o wartościach, normach i wzorach postępowania ${ }^{7}$.

Etyka realistyczna ma swoje podstawy w doświadczeniu moralnym osoby ludzkiej, nie skupia się zaś na doświadczeniu zmysłowym (obserwacji) zachowań grup ludzkich, społeczności. To od wyniku owego doświadczenia moralnego zależą przedsięwzięcia ku kształtowaniu społeczności. Ta różnica zwrotu relacji osoba-społeczność przekłada się na fundamentalną różnicę w praktyce (w metodach) formowania społeczności. W nurcie realistycznej etyki będzie to przede wszystkim wychowywanie każdego członka społeczności ${ }^{8}$, aby jako świadomy podmiot dokonywał właściwych wyborów w działaniu (nie jest to musztrowanie czy dyscyplinowanie w posłuchu). W nurcie socjologistycznym częściej będzie to sterowanie zachowaniem każdego członka społeczności, aby nabył stadnych (na podobieństwo instynktowych) odruchów reakcji na bodźce płynące od społeczności, czyli będą to zabiegi przypominające miękką tresurę.

Wiedza o społeczeństwie jest ważna dla ustawicznych badań nad naturą ludzką, zgłębiania treści doświadczenia moralnego w oparciu o jego przejawy w różnych kulturach i okresach historycznych, w zmieniającym się otoczeniu

\footnotetext{
$5 \quad$ Zob. T. Grabińska, Etyka a bezpieczeństwo personalne, Wrocław 2013.

6 Jak w Arystotelesowskich podstawach filozofii praktycznej: Arystoteles, Etyka nikomachejska, tłum. D. Gromska, Warszawa 2007; tenże, Polityka, tłum. L. Piotrowicz, [w:] tegoż, Dzieła wszystkie, t. 6, Warszawa 2001, s. 7-226.

$7 \quad$ Zob. J. Maritain, Wykład pierwszy, [w:] tegoż, Dziewięć wykładów o podstawowych pojęciach filozofii moralnej, tłum. J. Merecki, Lublin 2001.

8 Zob. np. M. Zabierowski, Pedagogika a zarzadzanie, Wrocław 2013; A. E. Szołtysek, Filozofia wychowania moralnego, Kraków 2009.
} 
przedmiotów naturalnych i tych, które są wytworem kultury, zwłaszcza dynamicznie rozwijających się współczesnych i projektowanych technologii ${ }^{9}$. Należałoby więc poszukiwać pewnego rodzaju sprzężenia zwrotnego między wiedzą socjologiczną a filozofią moralną. Jednak zautonomizowane i traktowane jako priorytet szczegółowe, tzw. naukowe rozważania, nakierowane na użyteczność ludzkiego działania, na manipulowanie ludzką grupa i zachowaniem poszczególnych osób, lokują się w niebezpiecznym sąsiedztwie z antyhumanistycznym i stechnicyzowanym podejściem do ludzkiej natury. I tu upatrujemy podstawowe niebezpieczeństwo we współczesnym świecie podstawowe, bo rodzącego inne zagrożenia dla człowieka i społeczności (będących m.in. przedmiotem nauk o bezpieczeństwie). Ale także podstawowe dlatego, że jest stałą troską papieskiego nauczania społecznego i przedmiotem realistycznej etyki, etyki personalistycznej.

\section{Bezpieczeństwo personalne a bezpieczeństwo społeczne w świecie współczesnym}

Współcześnie propagowane środki, niezbędne do zapewnienia bezpieczeństwa personalnego, stają się często jego zagrożeniem, bowiem prowadzą do braku poczucia sensu życia i doraźności szczęścia. Środki te to:

- coraz bogatsza oferta konsumpcji;

- wygodny sposób życia i nakierowanie na łatwo dostępne przyjemności, skupienie się na standardzie życia doczesnego;

- zindywidualizowanie sumienia ${ }^{10}$;

- pielęgnowanie egoizmów ${ }^{11}$.

Mają one gwarantować przeżywanie przyjemności, zabezpieczenie potrzeb w sferze materialnej, dobre zdrowie i kondycję fizyczną, pewność własnych

9 Zob. T. Grabińska, Transhumanizm - ochrona i zagrożenia bezpieczeństwa personalnego, [w:] System bezpieczeństwa wewnętrznego państwa. Synergia zagrożeń, cz. 1, red. H. Spustek, Wrocław 2014, s. 17-38.

${ }_{10}$ O uniwersalistycznie versus indywidualistycznie pojętym sumieniu zob. np. Jan Paweł II, enc. Veritatis splendor [dalej: VS], rozdz. II; oraz o błędzie indywidualizmu w: T. Grabińska, Liberalny kapitalizm i marksistowski kolektywizm a bład antropologiczny materiali$z m u$, „Zeszyt Naukowy” 3 (2000), s. 131-148, Wydział Zarządzania i Ekonomii WSzJOiE, Częstochowa.

11 EG 2. 
wyborów, brak zmartwień o sprawy wykraczające poza horyzont własnej egzystencji.

Równocześnie konsekwencją takiej postawy jest - wobec wzrastającego konsumizmu, hedonizmu i egoizmu - skupienie życia wewnętrznego wyłącznie na własnych interesach:

1. wobec hedonizmu, indywidualizmu i egoizmu - brak zainteresowania sprawami innych ludzi, ich problemami, także natury materialnej, co Franciszek nazywa "globalizacją obojętności" ${ }^{12}$;

2. wobec hedonizmu i indywidualizmu - lekceważenie przekazu religijnego podporządkowania życia doczesnego życiu wiecznemu;

3. wobec hedonizmu, indywidualizmu i egoizmu - brak zainteresowania i radości z nawiązywania relacji przyjaźni i miłości z bliźnimi;

4. wobec konsumizmu, hedonizmu, indywidualizmu i egoizmu - zanik znaczenia dobra ludzkiego czynu, w tym sensie - zanik wartości życia moralnego.

Postawa warunkowana konsumizmem, hedonizmem, indywidualizmem i egoizmem w rzeczywistości osłabia wolę życia i funduje stan społeczności nazywany przez Jana Pawła II cywilizacją śmierci, ufundowany na tzw. antilife mentality ${ }^{13}$ i prowadzący do dehumanizacji.

Gdzie indziej ${ }^{14}$ rozwinęłam koncepcję błędu antropologicznego liberalnego kapitalizmu ${ }^{15}$, którą Jan Paweł II wyprowadzał na podstawie ideologii liberalnego kapitalizmu z rekonstrukcji odpowiadającej jej ontologii - z materializmu. Błąd antropologiczny występuje zawsze wtedy, gdy człowiek jest traktowany przedmiotowo, gdy jego zachowania opierają się na mechanicznej relacji akcja-reakcja ${ }^{16}$, gdy cele człowieka są sprowadzane do używania dóbr, jak i używania innych ludzi, gdy w człowieku wyzwala się bardziej zachowania zwierzęce, jakby kierowane instynktami, niż osoby ludzkiej, kierującej się rozumem i budującej relacje miłości, gdy celem gospodarowania zasobami nie jest wszechstronny rozwój osoby ludzkiej, lecz zysk wybranych.

Sprowadzenie człowieka do sfery instynktowej, do mechanizmu reagującego na bodźce zewnętrzne, istoty zaangażowanej w zabieganie o własne

\footnotetext{
12 Tamże, 54.

13 Jan Paweł II, adhort. apost. Familiaris consortio, 30.

14 T. Grabińska, Liberalny kapitalizm..., dz. cyt.

15 Wyróżnikiem modelu gospodarowania liberalnego kapitalizmu jest u Jana Pawła II koncepcja wolności gospodarczej, która „nie jest ujęta w ramy systemu prawnego, wprzęgającego ją w służbę integralnej wolności ludzkiej i traktującego jako szczególny wymiar tej wolności, która ma przede wszystkim wymiar etyczny i religijny"; por. CA 13, 42; VS rozdz. II.

16 Jak np. w antropologii Tomasza Hobbesa: T. Hobbes, Lewiatan..., dz. cyt.
} 
korzyści i przyjemności zawsze prowadzi do dehumanizacji ludzkiego życia zarówno na poziomie jednostki, jak i wspólnoty. Świat ludzkich wytworów - kultura, która jest skutkiem działania potencjału specyficznie ludzkiego ${ }^{17}$, może zarówno służyć rozwojowi człowieczeństwa, jak i je unicestwić. Współcześnie palącą potrzebą jest ustosunkowanie się do nowego projektu, tzw. transhumanizmu ${ }^{18}$, i obrona przed nowym realnym zagrożeniem, pochodzącym od coraz już mniej przyszłościowych technologii GRIN ${ }^{19}$. Osiągnięcia technologii GRIN mogą przynieść człowiekowi i całej ludzkości wiele dobra, mogą zaspokoić wszelkie tzw. podstawowe potrzeby ludzkości w skali globalnej, mogą podnieść tzw. jakość życia i wyzwolić ludzką kreatywność, zaspokoić potrzebę radości z przyjaznych relacji z innymi. Mogą jednak spowodować destrukcję na niespotykaną skalę.

Zagrożenie jest wciąż to samo. Gdy górę biorą cele egoistyczne i żądza panowania nad innymi, może powstać trwała segregacja na tych, którzy (transludzie, docelowo - nadludzie) mają dostęp do najnowszych technologii cyborgizacji ludzkiego ciała i sfery mentalnej, i tych, którzy im już nie tylko służą, ale pozostają do wyłącznej ich dyspozycji. Uczynienie z indywidualnej przyjemności podstawowego celu życia jeszcze bardziej ten trend umacnia, ale też może doprowadzić, właśnie wskutek walki w nienasyceniu doznań przyjemności, do zniszczenia ludzkości.

Rozwój technologiczny pozwala człowiekowi żyć wygodniej i bezpieczniej oraz umożliwia szybką i skuteczną komunikację, ale tylko wtedy, gdy komunikacja spełnia swą pozytywną funkcję wzmocnienia poczucia bezpieczeństwa personalnego, gdy osiągnięcia technologiczne służą podniesieniu wartości każdej istoty ludzkiej, będą przebiegać ogólnokowariantnie ${ }^{20}$, nie zaś - jak to się dzieje - podlegać nieludzkiej ekonomii urynkowienia każdego człowieka do postaci przedmiotu wymiany, wykluczenia, unicestwienia, postawienia $\mathrm{w}$ stan hazardyzacji ${ }^{21}$ każdego ludzkiego pragnienia i potrzeby. W wyniku

17 M. Zabierowski, Potencjał ludzki a kapitał ludzki - rozważania antropologiczne, „Zeszyty Naukowe WSOWL” 13 (2011) 4 (162), s. 370-382.

18 T. Grabińska, Transhumanizm..., dz. cyt.

19 GRIN jest akronimem pochodzącym od angielskich nazw czterech głównych współczesnych dyscyplin badawczych: genetyka, robotyka, informatyka i nanotechnologia.

20 Ogólnokowariantnie znaczy współzmienniczo, tj. w sposób zharmonizowany ze zmianami środowiska społecznego i naturalnymi przeobrażeniami osoby ludzkiej.

21 Hazardyzacja oznacza tu wystawienie ludzkiego losu na bezwzględną grę rynkową o wszystko; zob. M. Zabierowski, Ile dobra ma najlepsza współczesna ideologia dobrej gospodarki?, „Res Humanae” 8P (2000), s. 137-181. 
tego „[1]ęk i rozpacz opanowują serca wielu osób, nawet w tak zwanych krajach bogatych. Często gaśnie radość życia, wzrasta brak szacunku i przemoc, nierówność społeczna staje się coraz bardziej oczywista" ${ }^{22}$.

Wykluczenie $\mathrm{z}$ faktycznego uczestnictwa w życiu publicznym i inicjatywie gospodarczej całych populacji (obok tych żyjących w krajach ubogich, w tzw. trzecim świecie), które zamieszkują kraje bogate, przodujące w postępie technologicznym, a także średnio zaawansowane technologicznie, nazywał Jan Paweł II zjawiskiem czwartego świata ${ }^{23}$. Deklarowanie równości i wolności obywatelskiej, równego dostępu do uczestnictwa w rynku nie gwarantuje podmiotowego traktowania obywatela krajów demokratycznych i kształtujących politykę światową. Tłumaczenie tego nieporadnością tych wykluczonych lub jakimś większym dystansem kulturowym nie wystarcza, tym bardziej że obserwacja zdarzeń w zjednoczonej Europie, gdy ją traktować jako przodujące, bogate i zaawansowane technologicznie superpaństwo, pokazuje proces tworzenia się owego czwartego świata krajów pokomunistycznych w pierwszym świecie Unii Europejskiej. Np. katastrofalna sytuacja demograficzna w Polsce, spowodowana dostarczaniem dobrze wykwalifikowanej siły roboczej dla bogatych państw UE oraz rozwinięcie głównie rynku konsumenckiego, a nie wytwórczości przemysłowej, angażującej postęp technologiczny i znaczącej w rozwijaniu najnowszych technologii są niewątpliwie wyznacznikami czwartego świata.

\section{Zniewolenie lękiem przed bliźnim}

Współczesny fiskalizm prawie wszystkie wartości zastępuje wartością pieniądza, a wszystkie godne cele ludzkiego działania - zyskiem finansowym. Jego dominacja unieważnia ludzką podmiotowość, godzi w podstawy antropologii chrześcijańskiej ${ }^{24}$. Ideał człowieka sprowadza do idealnego konsumenta, a w systemach zdemokratyzowanych dodatkowo do idealnego (tzn. przewidywalnego w interesie „niewidocznej tyranii”) wyborcy. Jan Paweł II wiele miejsca w encyklikach społecznych poświęcił zjawisku konsumizmu $^{25}$, czyli ogniskowania ludzkich celów i działań wokół konsumpcji

\footnotetext{
22 EG 52-54.

23 SRS 14.

24 EG 55-56.

25 CA 36.
} 
dóbr wytwarzanych coraz łatwiej i w coraz większej ilości - dóbr produkcji masowej, zarówno materialnych, jak i niematerialnych. Zjawisko to jest konsekwencją bardziej fundamentalnych błędów - błędu materializmu i błędu ekonomizmu ${ }^{26}$, czyli traktowania pracy $\mathbf{w}$ kategoriach celowości wylącznie ekonomicznej. Błędami tymi - materializmu i ekonomizmu - obarczony jest zarówno liberalny kapitalizm, jak i marksistowski kolektywizm. Różne są jednak przejawy tego błędu w formacjach społeczno-politycznych, opartych na tych ideologiach. Ideologia marksistowskiego kolektywizmu ufundowała w praktyce politycznej system totalitarny. Nie znaczy to jednak, że ideologia liberalnego kapitalizmu, dryfująca w kierunku konsumizmu i ekonomizmu, jest daleka od usprawiedliwienia totalnych rozwiązań w skali globu, zwłaszcza gdy jest wspomagana coraz to doskonalszymi technologiami informacyjnymi i wpływania na ludzkie wybory ${ }^{27}$.

W coraz liczniejszych społecznościach zurbanizowanych odczuwa się powszechnie brak poczucia bezpieczeństwa personalnego wskutek wzrostu przestępczości, działań mafijnych, handlu narkotykami, korupcji. Ale nie tylko z tego obiektywnego powodu ostatnimi czasy epatuje się zwykłych obywateli doniesieniami o otaczających ich zewsząd zagrożeniach. Tak jakby wrogiem miał być każdy członek rodziny, nawet najbliższy, sąsiad, członek innej grupy wyznaniowej, innej narodowości, o innym statusie społecznym itp. Nie zaniedbuje się straszenia mniej lub bardziej realnymi katastrofami naturalnymi, jak niebezpieczni przybysze z kosmosu, asteroidy mające zniszczyć planetę Ziemię, przebiegunowanie przynoszące liczne zaburzenia klimatyczne itd.

Pierwszą rzeczą jest zatem ocena, które i w jakim stopniu zagrożenia są realne, a które są instrumentem zniewolenia każdego indywiduum jego lękiem przed wszystkimi i wszystkim ${ }^{28}$. Następnie w przypadku realnych zagrożeń, jak wskazuje Franciszek, należy rozwinąć profilaktyką i prewencję,

\footnotetext{
26 T. Grabińska, Liberalny kapitalizm..., dz. cyt., s. 137.

27 Taż, Zagrożenia od nowych biotechnologii, „Logistyka” 4 (2014), s. 373-380, Logistyka - nauka, CD nr 1; taż, Transhumanizm..., dz. cyt.

28 Jest to kolejne świadectwo barbaryzacji kultury europejskiej. Oto Europa cofa się do czasów już nie tylko przedchrześcijańskich, ale przedfilozoficznych, gdy pierwsi filozofujący Grecy starali się wyzwolić człowieka z lęków przed przyrodą i nieodgadnioną wolą bogów. Różnica polega na tym, że w zateizowanym XXI wieku liczne technologie pozwalają przewidywać zagrożenia naturalne i przeciwdziałać ich skutkom. Staje się zatem tak, jakby wrogich sił i zła upatrywać należało w swym bliźnim. Jakby antropologia w rodzaju Hobbesowskiej stawała się podstawą rozumienia relacji międzyludzkich. Zob. np. T. Grabińska, Usposobienie..., dz. cyt.; taż, Żądza mocy Hobbesa podstawa pojmowania przedsiębiorczości
} 
polegające na usunięciu źródeł wrogości, zarówno w postaci zobiektywizowanej, jak i w postaci subiektywnych ludzkich odczuć. Elementarne, ale jakże zaniedbane ${ }^{29}$ jest głoszenie, że każda relacja między osobami musi być oparta na miłości, na służeniu sobą drugiemu, na darowaniu siebie i przyjmowaniu daru od bliźniego; a w żadnym wypadku relacja między osobami nie może opierać się na konkurencji, na demonstrowaniu indywidualizmów, na wyścigu do dóbr i zaszczytów, na nienawiści i zazdrości.

Przemoc w rodzinie jest generowana wieloma czynnikami, spośród których najważniejszy to rozpad tradycyjnych więzi wskutek przemian kulturowych, wzmocnionych ideologią postmodernizmu ${ }^{30}$. Rozpad rodziny ${ }^{31}$ jest pogłębiany przez programowe bezrobocie, zmianę ról społecznych kobiet i mężczyzn, wrogą rodzinie propagandę indywidualizmu i fałszywej autonomii każdego z członków rodziny, w tym - dzieci. Walka o reglamentowane miejsca pracy, przymus robienia kariery i stymulowanie tzw. wyścigu szczurów są podstawą wzajemnego antagonizowania pracowników. Wszechobecna niesprawiedliwość społeczna w skali globalnej, a także coraz szybciej rosnąca dywersyfikacja bogactwa w poszczególnych krajach i w stosunkach między krajami nastrajają wrogo ubogich do bogatych. W tej sytuacji, aby doraźnie zapobiegać aktom przemocy, wciąż doskonalone są systemy bezpieczeństwa i uzbrojenie, odgradzanie się bogatych od biednych murami i kordonem ochroniarzy czy zmyślnymi alarmami ${ }^{32}$.

\section{Bezpieczeństwo Kościoła a bezpieczeństwo wspólnoty globalnej}

Kościół ma całym sobą służyć wiernym, ale nie tylko im, lecz wszystkim ludziom pozostającym w potrzebie. Bezpieczeństwo Kościoła nie polega na skupieniu się na instytucjonalnym przetrwaniu w wyniku zamknięcia się na wyzwania świata - te odwieczne, wołające o sprawiedliwość, i te współczesne, zjawiające się wraz z dynamicznym rozwojem infrastruktury społecznej, technologicznej i globalizacyjnej.

i człowieka pracy, [w:] Młody człowiek wobec pracy, wyzysku, i bezrobocia, red. A. Hennel-Brzozowska, Kraków 2014, s. 65-86.

29 Zwłaszcza w obliczu propagowania hazardyzacji.

30 Zob. np. Postmodernizm i fundamentalizm a prawda - od idei do praxis, red.

H. Grzmil-Tylutki i A. Hennel-Brzozowska, Kraków 2010.

31 Zob. Jan Paweł II, List do rodzin.

32 EG 59, 60, 67, 75, 104. 
Rozwój Kościoła widzi Franciszek w podjęciu szeroko zakrojonego zadania ewangelizacji w duchu okazywania miłości tak zagubionym wiernym, jak i niechrześcijanom ${ }^{33}$. Bezpieczeństwo Kościoła jest niejako wypadkową bezpieczeństwa personalnego każdej ludzkiej istoty. Trzeba elementy tego bezpieczeństwa rozpoznać na zasadzie „ewangelicznego rozeznania” ${ }^{34} \mathrm{i}$ umacniać w powszechnej misji duszpasterzowania, tzn. nie tylko za pośrednictwem osób duchownych. Równocześnie Franciszek przestrzega osoby pracujące w duszpasterstwie przed relatywizmem życiowym (praktycznym), który jak pisze - jest niebezpieczniejszy od doktrynalnego, bo pozbawiony gorącego przesłania misji i ofiarowania się bliźnim. Przestrzega przed relatywizmem życiowym, polegającym na wykonywaniu standardowych czynności (poniekąd jak w zautomatyzowanej pracy zawodowej) w celu zapewnienia sobie (czasem środkami niedozwolonymi) bezpieczeństwa materialnego i wysokiej pozycji społecznej. Brak żarliwych katechetów, ale i kapłanów staje się widoczny. „Niektórzy stawiają opór, by dogłębnie zasmakować w misji i ogarnięci są paraliżującą acedią" ${ }^{35}$.

W celu wprowadzania w życie nowej ewangelizacji Franciszek wyraźnie wskazuje na konieczność korekty postaw tzw. antropocentrycznego immanentyzmu w religijności chrześcijan. Występują dwie odmiany tej postawy: gnostycyzm - prowadzący do polegania jedynie na subiektywnych sądach, zdobytej wiedzy, własnych odczuciach i doświadczeniu oraz prometejski neopelagianizm - usprawiedliwiający własne poczucie wyższości nad innymi z powodu dostosowywania się do norm i z powodu poczucia siły w samodzielnym działaniu. Wynikające $z$ tych postaw „domniemane bezpieczeństwo doktrynalne czy dyscyplinarne prowadzi do narcystycznego i autorytarnego elitaryzmu, gdzie zamiast ewangelizowania pojawia się analiza i krytyka innych, a zamiast ułatwiania dostępu do łaski - traci się energię na kontrolę". Te i inne tzw. światowe postawy duchowości są wyrazem tego, że „[e]wangeliczny zapał ustąpił miejsca nieautentycznej radości egocentrycznego samozadowolenia" ${ }^{36}$.

Franciszek podkreśla zdecydowanie, że jakkolwiek nad ideą i teoretycznym wyrazem religijności w stosunku do świata należy cały czas pracować, to - w duchu Arystotelesowskiego i Tomaszowego realizmu - rzeczywistość

\footnotetext{
33 Tamże, 49.

34 Tamże, 49, 50.

35 Tamże, 80, 81.

36 Tamże, 94.
} 
ma być podstawą owego opracowania: „rzeczywistość jest ważniejsza od idei. Pociąga to za sobą unikanie różnych form ukrywania rzeczywistości: angelicznych puryzmów, dyktatury relatywizmów, pustej retoryki, projektów bardziej formalnych niż realnych, fundamentalizmów antyhistorycznych, intelektualizmów pozbawionych mądrości”37.

W zwróceniu uwagi przez Franciszka na konieczność rozwijania żywej wiary we wspólnotach chrześcijańskich i w krytykowaniu przez niego nadmiernej intelektualizacji wiary nie należy, sądzę, upatrywać odejścia Franciszka od programu Fides et ratio Jana Pawła $\mathrm{II}^{38}$. Franciszek pragnie słusznie odnowić duszpasterską misję Kościoła i poszczególnych kapłanów, a nie przeciwstawiać się rzymskiej tradycji chrześcijaństwa, która akcentuje dwutorowość poszukiwania prawdy.

Istnieje podwójny porządek poznania, różniący się nie tylko źródłem, ale i przedmiotem. Różni się źródłem, bo w pierwszym przypadku poznajemy przy pomocy naturalnego rozumu, a w drugim przy pomocy wiary. Różni się przedmiotem, bo oprócz prawdy, do której może dojść rozum naturalny, przedłożone są nam również do wierzenia tajemnice zakryte w Bogu: nie można ich poznać bez Objawienia Bożego ${ }^{39}$.

Jan Paweł II próbował podnieść znaczenie filozofii w rozumieniu świata i wiedzy o świecie - ale filozofii w jej pełnym wydaniu systemowym ${ }^{40}$, filozofii, którą, podobnie jak wiarą, pogardza postmodernistyczny intelektualista. Równocześnie Jan Paweł II krytykował te nurty filozoficzne, które w nowożytności ograniczyły się do wąskiej antropologii, co doprowadziło „do powstania różnych form agnostycyzmu i relatywizmu, które sprawiły, że poszukiwania filozoficzne grzęzły na ruchomych piaskach powszechnego sceptycyzmu. [...] Uprawniona wielość stanowisk ustąpiła miejsca bezkrytycznemu pluralizmowi, opartemu na założeniu, ze wszystkie opinie mają równą wartość".

Dla Jana Pawła II i Franciszka mądrość w całej jej pełni nie jest mądrością tego świata, nie jest intelektualną wyrafinowaną grą z przejawami prawdy o świecie, wymaga pokory wobec tego co pojęte rozumem być nie może, co objawia się w tajemnicy Pisma i w tajemnicy odkupienia. „Mądrość Krzyża

\footnotetext{
37 Tamże, 231-233.

38 Jan Paweł II, enc. Fides et ratio [dalej: FeR].

39 I Sobór Watykański, konst. Dei Filius, rozdz. IV: DS 3015.

40 FeR 3, 4 i duże fragmenty rozdziałów V i VI.
} 
przekracza [...] wszelkie granice kulturowe, jakie można by jej narzucić, i każe otworzyć się na powszechność zawartej w niej prawdy"41. Zdawał się to rozumieć Leszek Kołakowski, gdy pisał, być może zbyt pesymistycznie, o bezradności współczesnych intelektualistów. „Tymczasem my - «my» to znaczy filozofowie, socjolodzy, psycholodzy, antropolodzy, historycy - nie możemy niczym przyczynić się do tego procesu [odrodzenia religijnego], możemy go opisywać - z nadzieją lub strachem - ale nie jesteśmy kapłanami, a tylko przez kapłaństwo, proroctwo, akty wiary żywej utrzymuje się i wzmacnia udział człowieka w sacrum" ${ }^{42}$. O to właśnie chodzi Franciszkowi w Evangelii gaudium, gdy pisze z troską o odrodzeniu Kościoła. W podobnym duchu pisał o posłannictwie Kościoła Jan Paweł II w pierwszej swojej encyklice Redemptor hominis ${ }^{43}$.

\section{Etyka w służbie bezpieczeństwa personalnego i społecznego}

Teoria moralności jako tradycyjny dział filozofii praktycznej ma określać cel i sens ludzkiego życia - szczęście (eudajmonię) i porządek ludzkich wysiłków, prowadzących do urzeczywistnienia go. Celem ludzkiego życia ma być - od starożytnych - szczęście, a zatem właściwym stanem duchowym ma być radość. Radość jako wyraz odczuwanego szczęścia ma być powodowana stanem ludzkiego ducha, ma być uwarunkowana przede wszystkim wewnętrznie.

Warunki zewnętrzne mogą sprzyjać lub przeszkadzać ziszczeniu się szczęścia, ale nie są decydujące dla jego osiągnięcia. Szczęście i poczucie bezpieczeństwa nie są wprost proporcjonalne do poziomu bogactwa ${ }^{44}$. O radości istnienia decyduje pozytywna relacja do bliźnich (jak arystotelesowska przyjaźń ${ }^{45}$ ), a w horyzoncie chrześcijańskim - miłość bezwarunkowa, jak w tajemnicy odkupienia - „spotkanie z wydarzeniem, z Osobą, która nadaje życiu nową perspektywę, a tym samym decydujące ukierunkowanie" ${ }^{\prime 6}$.

\footnotetext{
41 Tamże, 23.

42 L. Kołakowski, Chrystus ośmieszony. Esej apologetyczny i sceptyczny, tłum. D. Zańko, Kraków 2014, s. 100.

43 Jan Paweł II, enc. Redemptor hominis [dalej: RH].

44 T. Grabińska, Etyka..., dz. cyt.; zob. taż, Zagrożenia bezpieczeństwa w ideologii transhumanizmu, „Kultura Bezpieczeństwa. Nauka - Praktyka - Refleksje” 18 (2015), s. 52-73.

45 Arystotelesa, Etyka..., dz. cyt., ks. VIII-IX.

46 Benedykt XVI, enc. Deus caritas est, 21; zob. też RH, rozdz. III.
} 
Zgodnie z tymi słowami Benedykta XVI cytowanymi przez Franciszka ${ }^{47}$ chrześcijanin niejako przyjmuje przez wiarę teorię moralności, nie wybiera jej z zestawu filozoficznych propozycji. To prawda, ale równocześnie zasługą Kościoła rzymskiego jest nieporównywalny z dorobkiem innej myśli religijnej wysiłek włączenia dorobku filozofii do wyrażania tez teologicznych i uzasadniania konsekwencji prawd objawionych w praktyce życia. Jan Paweł II dlatego tak mocno podkreślał znaczenie antropologii (koncepcji człowieka - teologicznej i filozoficznej) ${ }^{48}$ dla zrozumienia dylematów współczesnego świata, także świata chrześcijan - katolików, protestantów i prawosławnych, którzy różniąc się niektórymi elementami rozumienia człowieka jako boskiego stworzenia i relacji człowieka do Boga, wytworzyli różniące się etyki, a co za tym idzie - modele formowania człowieka oraz relacji człowieka do wspólnoty. Chrześcijanin więc, wraz z przynależnością do określonego kościoła, jest także kształtowany przez jego wspólnotę, zgodnie z tradycją, do której należy koncepcja moralności.

W związku z podziałem chrześcijaństwa i poszukiwaniem ewangelicznej jedności Franciszek za Soborem Watykańskim II $^{49}$ przypomina o hierarchii prawd wiary ze względu na ich bliskość istoty Ewangelii, z których najważniejsza wskazuje na „piękno w zbawczej miłości objawionej w Jezusie Chrystusie, który umarł i zmartwychwstał" ${ }^{50}$. Boska miłość do stworzenia przekłada się na najważniejszą cnotę chrześcijanina działającego w świecie zewnętrznym - miłosierdzie. „Jej właściwością bowiem jest dawanie innym; a co więcej, zaradzanie potrzebom cudzym, a to jest dowodem wyższości”51. Działanie przez miłość jest najważniejszym świadectwem wiary i łaski Ducha Świętego w umacnianiu „zadziwienia, fascynacji, entuzjazmu z życia Ewangelią braterstwa i sprawiedliwości!" 52 .

Chrześcijańskie przepowiadanie moralne to coś więcej niż etyka jako filozofia moralności, coś więcej niż zasady ludzkiego działania i ich spójne uzasadnienie. To, co jest owocem obcowania chrześcijanina z Bogiem, uczestnictwa w jego dziele stworzenia, rozpoznania Boga w stworzeniu. To, co

$47 \quad$ EG 7.

48 FeR 9 i inne ustępy; o błędzie antropologicznym: CA 13; T. Grabińska, Liberalny kapitalizm..., dz. cyt.

49 Sobór Watykański II, dekret Unitatis reintegratio, 11.

50 EG 36.

51 Tomasz z Akwinu, Summa theologica II-II, q. 30, a. 4.

52 EG 179, 37, 193. 
jest służbą w odpowiedzi miłości. Żywość przepowiadania moralnego chroni Kościół przed ideologicznym skostnieniem ${ }^{53}$.

\section{Niektóre inne realne zagrożenia w świecie współczesnym}

W trosce o dialog Kościoła ze współczesnością Franciszek dostrzega potrzebę analizy tradycji Kościoła pod kątem zdezaktualizowania niektórych zwyczajów oraz rewizji norm i przykazań kościelnych w celu zachowania i uwypuklenia tych, które odpowiadają na potrzeby formacji współczesnego chrześcijanina. Powołuje się na św. Tomasza z Akwinu, który w XIII wieku przestrzegał przed dodawaniem do bardzo nielicznych ewangelicznych prawd wiary przykazań kościelnych, nazbyt ograniczających chrześcijanina. Dotyczy to współcześnie także przepowiadania moralnego Kościoła. Do sprawy należy podejść z dużą ostrożnością i mądrością, aby nie popaść w nadmierną liberalizację wymagan ${ }^{54}$.

I tak w świecie chrześcijańskim rozpanoszyły się obce Ewangelii ideologie: rynkowa i ubóstwienia pieniądza. Franciszek wyraźnie nawołuje do „bezinteresownej solidarności oraz do przywrócenia ekonomii i finansom etyki sprzyjającej człowiekowi”" ${ }^{5}$. Ideologie te pochodzą - jak to nazywa Franciszek - od „kultur rozwiniętych gospodarczo, ale etycznie osłabionych". Kultury te siłą swego politycznego, gospodarczego i militarnego wpływu podporządkowują sobie terytoria i słabsze społeczności, demoralizując je w wyniku niszczenia ich tradycyjnych systemów wartości ${ }^{56}$. W tym miejscu mówi jednym głosem $\mathrm{z}$ Janem Pawłem II, który po wielekroć $\mathrm{w}$ wielu homiliach i wszystkich trzech encyklikach społecznych domagał się podporządkowania celów ekonomicznych rozwojowi pełni człowieczeństwa każdego poszczególnego człowieka. Rozwijał zasadę solidarności jako społeczny wyraz relacji chrześcijańskiej miłości bliźniego ${ }^{57}$.

Wraz z urynkowieniem ludzkiego życia (hazardyzacją - pełnym ulosowieniem ludzkiego życia) w krajach bogatych i rozwiniętych postępuje proces sekularyzacji, mający na celu usunięcie religii z płaszczyzny społecznej do

\footnotetext{
53 Tamże, 39. Zob. np. VS, rozdz. I i rozdz. II. IV.

54 EG 43-44.

55 Tamże, 58.

56 Tamże, 62.

57 Np. liczne fragmenty w: LE; SRS; CA; VS; T. Grabińska, M. Zabierowski, Aksjologiczny krąg solidarności. Rekonstrukcja uniwersalizmu solidarnościowego i jego uzasadnienie w nauce społecznej Jana Pawła II, Wrocław 1998.
} 
sfery prywatnej, relatywizację prawdy i subiektywizowanie poglądów, zindywidualizowanie osądów sumienia, krzewienie wzorów wolności negatywnej (zwłaszcza uwolnienia od zasad religijnych i etycznych), absolutyzację autonomii jednostki. Nawołuje Franciszek do nauczania krytycznego myślenia, które umożliwi odkrywanie wartości, jak i identyfikowanie pseudowartości $\mathrm{w}$ chaotycznym przekazie medialnym. Potrzebna jest pilnie inkulturacja wiary, odnowa humanizmu chrześcijańskiego zwłaszcza w zamożnych krajach o tradycji chrześcijańskiej ${ }^{58}$.

Podobnie Jan Paweł II przeciwstawiał się deuniwersalizacji koncepcji sumienia, którego właściwą funkcją jest umożliwienie osobie rozumowego poznania, w wyniku czego jest ona zdolna „Zastosować wiedzę uniwersalną o dobru i tym samym wyrazić swój sąd o tym, jaki sposób postępowania należy uznać tu i teraz za słuszny"59. Gdy kultura zostaje skażona błędem indywidualizmu ${ }^{60}$, to kryterium prawdy zastępowane jest przez „kryterium szczerości, autentyczności, «zgody z samym sobą»" "', a osobie ludzkiej grozi utrata tożsamości nie tylko kulturowej, ale też psychologicznej, oraz alienacja spośród społeczności.

Tradycja filozoficzna doktryny Kościoła rzymskiego faworyzuje antropologie całościowe, ujmujące osobę w jedności psychofizycznej oraz we wszechstronnych relacjach do wspólnoty, i to w wymiarze pokoleń przeszłych i przyszłych, świata przyrody i świata nadprzyrodzonego. Antropologie redukcjonistyczne, sprowadzające człowieka bądź do materialności, bądź duchowości, jaźni czy psychiczności itp., łatwo dopuszczają rozwijanie nurtów indywidualistycznych, wprowadzanie konwencjonalnych zasad postępowania $\mathrm{w}$ relacjach międzyludzkich, jak i w urządzeniu społecznym (np. urynkowienie wszelkich stosunków człowieka ze światem, nie tylko tych, które od zawsze są naturalne dla transakcji wymiany dóbr), a nawet komercjalizację wierzeń religijnych. To w nich należy upatrywać źródło relatywizmu moralnego, egoizmu, nihilizmu w poznaniu ${ }^{62}$.

Antropologie redukcjonistyczne dopuszczają etykę utylitarystyczną ${ }^{63}$, która co prawda w jej szczegółowej wykładni słusznie podkreśla wartość wspólnego pożytku indywidualnego ludzkiego czynu, jednak w potocznym

58 EG 63, 64, 68; np. SRS, rozdz. III i V; CA, rozdz. VI.

59 VS 32; rozdz. II. II.

60 T. Grabińska, Liberalny kapitalizm..., dz. cyt.

${ }_{61}$ Jan Paweł II, enc. Evangelium vitae, 32.

62 VS 84.

63 Np. M. Zabierowski, Personalistyczna krytyka utylitaryzmu. Antropologiczna analiza brytyjskiej filozofii czynu, [w:] Personálna obnova humanity na prahu 21. storočia, red. M. Klo- 
przekazie, wzmocnionym wciąż żywym pozytywistycznym kanonem wiedzy i działania, dryfuje w kierunku nadawania wartości tylko takiej ludzkiej aktywności, która wprost i doraźnie przekłada się na zastosowania technologiczne lub na sukces finansowy. Tak zorientowany ludzki czyn traci całą swą moc doskonalącą moralnie jego sprawcę - jako osobę ${ }^{64}$. Powoduje ponadto niebezpieczny stan bezwzględnej rywalizacji o rzeczy i pieniądze, który pogłębia hazardyzację ludzkiego losu, wystawia każde ludzkie działanie na ryzyko, sztucznie wytworzone przez tzw. grę interesów, przyczynia się do permanentnego poczucia krzywdy i samotności współczesnego człowieka, wywołuje cywilizacyjną epidemię depresji ${ }^{65}$.

Franciszek, zgodnie z tytułem adhortacji Radość Ewangelii, przypomina, że chrześcijańska etyka, artykułowana w katechezie, powinna być optymistyczna i ukazująca dobro, piękno i prawdę jako cel ludzkich wysiłków, wysiłków wypełnianych $\mathrm{z}$ radością, ku przekroczeniu doczesnych trudów życia. Taką postawę należy kształtować wśród wiernych i taką postawą powinni świadczyć chrześcijanie wśród wyznawców innych religii i ateistów ${ }^{66}$.

Przekaz chrześcijańskiego miłosierdzia i uniwersalizmu należy szczególnie podkreślać zwłaszcza w dialogu z przywódcami krajów islamskich, tak bardzo szafujących ideologią religijną islamu, który przecież źródłowo akceptuje nauczanie Chrystusa, co prawda nie uznając go za Boga, lecz za proroka. Wrogość do chrześcijaństwa, zwłaszcza pozostającego w obecnej nieagresywnej formie, pogłębiają czynniki polityczne, rozgrywki między państwami lub grupami społecznymi i politycznymi interesu (niekoniecznie wyłącznie islamskimi) ${ }^{67}$. Przyczyny tego należy badać.

Podsumujmy nasze rozważania w odniesieniu do realizacji celów nakreślonych we wstępie.

bušická, M. Jozek, Nitra 2009, s. 105-116; T. Grabińska, Etyka..., dz. cyt., rozdz. 6, 15, 16; taż, Zagrożenia bezpieczeństwa $w$ ideologii transhumanizmu, dz. cyt.

${ }^{64}$ K. Wojtyła, Osoba..., dz. cyt.; VS, rozdz. II. IV.

65 Np. T. Grabińska, Żądza mocy..., dz. cyt.

66 EG 168.

67 Np. Holokaust chrześcijan,www.m.polska24.pl/blog/redakcja [30.01.2015]; P. Krysa, Neron wiecznie młody, www.opoka.org.pl/biblioteka/T/TH/THW/neron_mlody.html [30.01.2015]. 
Po pierwsze, Franciszek w adhortacji Evangelii gaudium rozwija myśl społeczną Jana Pawła II m.in. w następujących tezach.

1) W świecie postępuje dehumanizacja jako konsekwencja dechrystianizacji.

2) Urządzenia ekonomiczne muszą służyć każdemu człowiekowi, nie zaś wykluczać całe populacje z uczestnictwa w inicjatywie gospodarczej.

3) Zysk nie może być celem ludzkiego działania ani w wymiarze indywidualnym, ani grupowym, ani instytucjonalnym.

4) Pieniądz jest narzędziem ułatwiającym wymianę dóbr, nie zaś narzędziem władzy.

5) Nierówności społeczne powinny zostać wyeliminowane w zrównoważonym rozwoju ludzkości.

6) Tożsamość kulturowa poszczególnych grup i narodów powinna zastać zachowana i pielęgnowana.

7) Konieczna jest nowa ewangelizacja, zwłaszcza we wspólnotach zurbanizowanych.

8) Świat powinien się wyrzec przemocy, wojen i zbrojeń.

9) Konieczny jest dialog międzyreligijny.

Po drugie, papieskie rozważania - zarówno Jana Pawła II, jak i Franciszka - pozwalają rzucić światło na współczesne zjawisko lęku, powstające we współczesnym człowieku. Oto niektóre punkty papieskiej zobiektywizowanej diagnozy.

1) Laicyzacja i skupienie na celach życia doczesnego pozbawia człowieka nadziei i wiary w sens własnego działania, pesymizm moralny.

2) We wspólnotach zurbanizowanych postępuje alienacja ich członków, rozpadają się więzi rodzinne, sąsiedzkie, grupowe, co prowadzi do poczucia osamotnienia.

3) Ideologia hedonizmu i indywidualizmu jest przyczyną rodzącej się wrogości między osobami, a w konsekwencji - przyczyną załamania i depresji.

4) Ideologia rynkowa i komercjalizacja wszelkiego działania, przeniesione na wszystkie sfery ludzkiego życia, pobudzają do wyścigu o wymierne dobra oraz powodują stan stałego nienasycenia i lęku przed utratą osiągniętej pozycji lub zgromadzonego majątku.

Po trzecie, poczucie bezpieczeństwa w odniesieniu do osoby w nauczaniu papieskim, zarówno Jana Pawła II, jak i Franciszka, oznacza najogólniej radość z przeżywania każdej chwili życia doczesnego w horyzoncie eschatologicznym. Aby człowiek w tym sensie czuł się bezpieczny, musi: 
1) mieć głęboką wiarę; 2) odczuwać wsparcie rodziny i innych wspólnot, w których przyszło mu żyć; 3) doskonalić się moralnie w działaniu dla dobra innych; 4) przyjmować od bliźnich i przekazywać im dar miłości; 5) mieć wolność działania, głoszenia prawdy i tworzenia; 6) nie być zdanym na uprzedmiotowienie ze strony ideologii i instytucji; 7) nie podlegać przymusowi fizycznemu lub duchowemu; 8) nie uczestniczyć w wojnach. 